\title{
The Trade Impact of the Integration of the Central and Eastern European Countries on the European Union
}

\author{
Carmela Martin and Jaime Turrion \\ European Economy Group-UCM and FUNCAS
}

\begin{abstract}
This paper analyses the determinants of trade patterns between the CEECs and the OECD countries since the latter began their processes of transition and opening-up within the framework of the Association Agreements with the EU, with the ultimate aim of helping to anticipate the trade impact of their accession to the $E U$. To this end, we estimate an empirical model for a set of countries formed by the EU states, the CEECs and-by way of a control area- the other members of the OECD. Thus, we obtain new evidence about the determinants of the trade shares of the countries analysed. In addition, by using the corresponding dummies, we confirm that the Association Agreements have led to a preferential expansion of the exchanges between the EU and CEECs.

- JEL Classifications: F15, F23, P20

- Key words: European integration, Trade, Central and Eastern European Countries (CEECs)
\end{abstract}

\section{Introduction}

The enlargement of the European Union (EU), with the accession of as many as ten of the Central and Eastern European Countries (CEECs): Hungary, Poland, Czech Republic, Slovenia, Estonia, Romania, Bulgaria, Slovak Republic, Latvia and Lithuania ${ }^{1}$, represents a crucial episode in the construction of Europe due to its

\footnotetext{
*Corresponding address: Carmela Martin (carmelamartin@ccee.ucm.es), Jaime Turrion (ecap2z2@sis.ucm.es) European Economy Group(EEG), Facultad de Ciencias Económicas, Universidad Complutense de Madrid(UCM), Campus de Somosaguas, 28223, Madrid (Spain) Tlf: +34 9139424 54; +34 9135902 81, Fax: +34 913942457

(C2003-Center for International Economics, Sejong Institution, All Rights Reserved.
} 
political and economic implications, not only for the candidates, but also for the present members.

Although the formal beginning of negotiations is more recent ${ }^{2}$, the CEEC accession process somehow began in the early 90s, therefore shortly after their transition towards the free market system got under way. In fact, since then the candidates have been signing bilateral agreements with the EU -the so-called European Association Agreements- which have represented an advance in the path towards integration through stipulating a progressive liberalisation of trade and of direct investment flows.

In this respect, it may be argued that analysis of what has happened during the years while the above-mentioned agreements have been in force, not only as regards trade adjustments but also the trends in direct investment flows and the behaviour of the multinationals ${ }^{3}$, is valuable information with a view to predicting what may happen after these countries become full members of the EU. In turn, there is no doubt that these efforts of prediction are important for setting the process of negotiating the accession of these countries on the right lines, so that it may prove to be as beneficial as possible for both present and future members.

We have therefore approached this paper with the idea of helping to predict the likely effects of the accession of the CEECs on trade patterns in the enlarged EU. To this end, we examine the factors that account for the major changes that have taken place in trade flows since the CEECs began their processes of transition and economic opening-up within the framework of the European Association Agreements ${ }^{4}$. Specifically, our purpose is to find evidence that help us to foresee whether the accession of the CEECs will involve not only increased trading with the new partners -attributable to the effects of trade creation and deviation,

\footnotetext{
${ }^{1}$ Besides the ten CEECs mentioned, there are another two, Malta and Cyprus, which have also started the formal process of negotiating their accession to the EU.

${ }^{2}$ Specifically, Hungary, Poland, Czech Republic, Slovenia and Estonia started negotiations in March 1998, whereas the other CEECs did so in December 1999.

${ }^{3}$ The same may not be said, however, as regards migration flows, for which past experience is less useful with a view to drawing inferences for the future, as hitherto these have been subject to strict controls on the part of the EU countries.

${ }^{4}$ Hungary and Poland signed those Agreements in 1991. The Czech Republic did it in 1993 and Estonia and Slovenia in 1995 and 1996, respectively.
} 
acknowledged on a general basis in the literature on the Regional Integration Agreements- but also a geographical restructuring of the trade flows between the members of the area. Due attention has not been attached until recently to this latter aspect in the context of the new geography and trade models, although it is of equal importance. In this respect, it is of particular interest to us to examine whether -as has been postulated in some papers- the integration of the CEECs may lead to a concentration of the multinationals in these countries with a view to using them as a "exporting platform" in detriment to the exporting possibilities of the current members of the EU, and particularly of the Southern European member states, which have a more similar production and trading capacity to the candidates.

In order to advance in the knowledge of these issues, the paper is structured in the following way. Section 2 describes the stylised facts of the modifications that have been implemented in trading between the EU and the CEECs and, in order to have a suitable third area of control, the rest of the OECD countries (which, furthermore, are the ones that absorb practically all the remaining trade both of the current members of the EU and of the applicants). Section 3 outlines some brief considerations in relation to the hypotheses upheld in the models developed -as a result of the appearance of Krugman's influential book (1991)which attempt to explain trade in terms of imperfect competition, where "geography matters", and we then put forward an empirical model which sets out to be compatible with the theoretical hypotheses and with the stylised facts analysed previously. In section 4 an econometric estimation of the model is carried out -for a data panel of a set of countries made up of the current members of the OECD and other of the applicants for accession to the EU not yet forming part of this organisation, referring to the period 1988-98- and the results are discussed. The paper ends with a section of conclusions, where we summarise the main results obtained.

\section{Features of the Trade Opening-up of the CEECs}

One of the essential features denoting the process of transition of the former communist countries now engaged in negotiating their accession to the EU is their swift and intense opening-up to trade and international investment, oriented primarily towards Europe. In fact, shortly after the fall of the Berlin Wall and the collapse of the COMECOM, the CEECs stepped up their trading with the Western 
economies and particularly with the countries of the EU, which has now become the main supplier and destination of their expanding trading operations. Similarly, since the start of their transition to the free market system most of the CEECs have been receiving substantial and increasing flows of foreign capital in the form of direct investment, to the extent that foreign direct investment -which has played an active part in the privatisation processes in some of the CEECs - may also be considered to be a factor specific to the economic change that has taken place in these countries.

Table 1. Shares of the EU Countries, United States and Japan in the Imports of the CEECs

\begin{tabular}{|c|c|c|c|c|c|c|c|c|c|c|}
\hline & \multicolumn{2}{|c|}{ Czech Republic } & \multicolumn{2}{|c|}{ Hungary } & \multicolumn{2}{|c|}{ Poland } & \multicolumn{2}{|c|}{ Slovenia } & \multicolumn{2}{|c|}{ Estonia } \\
\hline & 1992 & 1998 & 1992 & 1998 & 1992 & 1998 & 1992 & 1998 & 1992 & 1998 \\
\hline Germany & 28.86 & 32.18 & 23.41 & 27.75 & 23.07 & 26.19 & 14.79 & 22.02 & 14.13 & 9.17 \\
\hline Austria & 5.82 & 4.99 & 14.11 & 9.21 & 4.27 & 1.85 & 8.46 & 10.11 & 0.57 & 0.74 \\
\hline $\begin{array}{l}\text { Belgium-Lux- } \\
\text { embourg }\end{array}$ & 1.72 & 2.01 & 1.99 & 2.53 & 2.12 & 2.89 & 0.43 & 1.73 & 4.34 & 1.40 \\
\hline Denmark & 0.78 & 0.65 & 0.61 & 0.60 & 1.84 & 1.88 & 0.24 & 0.46 & 3.15 & 2.72 \\
\hline Spain & 0.56 & 1.27 & 0.62 & 1.58 & 1.14 & 2.49 & 0.41 & 2.27 & 0.24 & 0.63 \\
\hline Finland & 0.40 & 0.87 & 1.02 & 1.04 & 1.56 & 1.59 & 0.23 & 0.31 & 36.68 & 31.77 \\
\hline France & 3.46 & 4.19 & 3.04 & 4.83 & 4.15 & 6.32 & 4.44 & 11.93 & 2.57 & 1.75 \\
\hline $\begin{array}{l}\text { United King- } \\
\text { dom }\end{array}$ & 2.10 & 3.50 & 2.88 & 3.39 & 6.19 & 4.77 & 0.85 & 2.21 & 1.74 & 2.41 \\
\hline Greece & 0.34 & 0.18 & 0.28 & 0.19 & 0.32 & 0.19 & 0.04 & 0.19 & 0.02 & 0.07 \\
\hline $\begin{array}{l}\text { The Nether- } \\
\text { lands }\end{array}$ & 1.77 & 2.24 & 2.95 & 2.48 & 4.34 & 3.68 & 0.66 & 2.36 & 1.73 & 2.37 \\
\hline Ireland & 0.12 & 0.42 & 0.14 & 0.42 & 0.27 & 0.50 & 0.01 & 0.24 & 0.07 & 0.28 \\
\hline Italy & 3.92 & 4.95 & 6.28 & 7.49 & 6.69 & 9.25 & 8.71 & 18.81 & 0.81 & 2.53 \\
\hline Portugal & 0.01 & 0.10 & 0.06 & 0.33 & 0.02 & 0.23 & 0.11 & 0.06 & 0.02 & 0.07 \\
\hline Sweden & 0.97 & 1.21 & 1.85 & 1.17 & 0.51 & 2.82 & 0.51 & 1.17 & 13.64 & 9.91 \\
\hline $\begin{array}{l}\text { European } \\
\text { Union(15) }\end{array}$ & 50.83 & 58.76 & 59.24 & 63.02 & 57.63 & 64.65 & 39.89 & 73.87 & 79.71 & 65.83 \\
\hline United States & 1.73 & 3.48 & 2.85 & 3.82 & 3.20 & 3.55 & 0.63 & 1.22 & 10.50 & 1.93 \\
\hline Japan & 1.21 & 1.73 & 2.38 & 3.83 & 2.03 & 1.87 & 0.20 & 0.77 & 0.38 & 0.43 \\
\hline $\begin{array}{l}\text { Rest of the } \\
\text { OECD }(*)\end{array}$ & 2.54 & 3.46 & 4.22 & 4.25 & 7.28 & 8.10 & 2.52 & 3.69 & 0.76 & 2.22 \\
\hline
\end{tabular}

(*)Not including Hungary, Poland and Czech Republic.

Source: OECD: International Trade by Commodity Statistics, OECD: Monthly Statistics of Foreign Trade and IMF: Direction of Trade Statistics Yearbook 
Table 2. Shares of the CEECs in the Imports of the EU Countries, United States and Japan

$(\%)$

\begin{tabular}{|c|c|c|c|c|c|c|c|c|c|c|}
\hline & Czech Republic & \multicolumn{2}{c|}{ Hungary } & \multicolumn{2}{c|}{ Poland } & \multicolumn{2}{c|}{ Slovenia } & \multicolumn{2}{c|}{ Estonia } \\
\hline & 1992 & 1998 & 1992 & 1998 & 1992 & 1998 & 1992 & 1998 & 1992 & 1998 \\
\hline Germany & 0.86 & 1.96 & 0.71 & 1.70 & 1.28 & 1.88 & 0.29 & 0.52 & 0.01 & 0.04 \\
\hline Austria & 1.22 & 2.28 & 1.95 & 3.29 & 0.88 & 0.83 & 0.48 & 0.90 & 0.00 & 0.02 \\
\hline $\begin{array}{c}\text { Belgium- } \\
\text { Luxem- } \\
\text { bourg }\end{array}$ & 0.11 & 0.32 & 0.16 & 0.42 & 0.26 & 0.43 & 0.02 & 0.06 & 0.00 & 0.02 \\
\hline Denmark & 0.25 & 0.36 & 0.16 & 0.25 & 1.28 & 1.72 & 0.05 & 0.14 & 0.07 & 0.25 \\
\hline Spain & 0.13 & 0.25 & 0.12 & 0.29 & 0.18 & 0.30 & 0.02 & 0.06 & 0.00 & 0.02 \\
\hline Finland & 0.29 & 0.44 & 0.36 & 0.38 & 1.33 & 0.87 & 0.04 & 0.07 & 0.57 & 1.76 \\
\hline France & 0.13 & 0.31 & 0.18 & 0.38 & 0.27 & 0.49 & 0.14 & 0.31 & 0.00 & 0.02 \\
\hline $\begin{array}{c}\text { United } \\
\text { Kingdom }\end{array}$ & 0.12 & 0.28 & 0.09 & 0.28 & 0.27 & 0.32 & 0.03 & 0.05 & 0.00 & 0.04 \\
\hline Greece & 0.52 & 0.38 & 0.31 & 0.28 & 0.23 & 0.34 & 0.01 & 0.09 & 0.03 & 0.01 \\
\hline $\begin{array}{c}\text { The Nether- } \\
\text { lands }\end{array}$ & 0.17 & 0.33 & 0.16 & 0.54 & 0.46 & 0.70 & 0.02 & 0.08 & 0.01 & 0.13 \\
\hline Ireland & 0.09 & 0.08 & 0.03 & 0.60 & 0.40 & 0.13 & 0.02 & 0.01 & 0.00 & 0.01 \\
\hline Italy & 0.28 & 0.45 & 0.51 & 0.61 & 0.05 & 0.04 & 0.22 & 0.57 & 0.00 & 0.01 \\
\hline Portugal & 0.06 & 0.19 & 0.03 & 0.17 & 0.04 & 0.11 & 0.02 & 0.04 & 0.01 & 0.02 \\
\hline Sweden & 0.15 & 0.53 & 0.30 & 0.32 & 0.83 & 1.13 & 0.08 & 0.12 & 0.19 & 0.84 \\
\hline & & & & & & & & & & \\
\hline $\begin{array}{c}\text { European } \\
\text { Union (15) }\end{array}$ & 0.37 & 0.76 & 0.39 & 0.79 & 0.57 & 0.78 & 0.15 & 0.28 & 0.02 & 0.09 \\
\hline & & & & & & & & & & \\
\hline $\begin{array}{c}\text { United } \\
\text { States }\end{array}$ & 0.04 & 0.07 & 0.07 & 0.17 & 0.07 & 0.09 & 0.02 & 0.03 & 0.00 & 0.01 \\
\hline Japan & 0.05 & 0.03 & 0.05 & 0.11 & 0.07 & 0.03 & 0.00 & 0.01 & 0.00 & 0.00 \\
\hline $\begin{array}{c}\text { Rest of the } \\
\text { OECD }(*)\end{array}$ & 1.41 & 1.41 & 0.94 & 1.18 & 1.53 & 2.44 & 0.17 & 0.47 & 0.04 & 0.53 \\
\hline & & & & & & & & & & \\
\hline
\end{tabular}

(*)Not including Hungary, Poland and Czech Republic.

Source: OECD: International Trade by Commodity Statistics, OECD: Monthly Statistics of Foreign Trade and IMF: Direction of Trade Statistics Yearbook.

To examine the features of the process of the trade opening-up of the CEECs ${ }^{5}$, we have prepared TABLES 1 and 2. The first contains information on the trend and current size of the export shares of the EU countries, the USA and Japan in

\footnotetext{
${ }^{5}$ Note that both here and in the rest of the paper, the acronym CEECs is used to refer to the five Central and Eastern European countries that started first and have their EU accession negotiations at the most advanced stage. Namely: Hungary, Poland, Czech Republic, Slovenia and Estonia
} 
each of the CEECs, and the second the values of the shares that the latter have in the afore-mentioned markets. Note that the information on the trend and geographical structure of trade is presented in the form of shares, because in this way the changes that have taken place in the role of the EU Member States visa-vis that of the other OECD countries, as suppliers and customers of the emerging markets represented by the candidates, can be shown more clearly.

Table 3. Stocks of Direct Foreign Investment Made by the EU Countries United States and Japan in the CEECs

\begin{tabular}{|c|c|c|c|c|c|c|c|c|c|c|}
\hline \multicolumn{11}{|l|}{ Million \$US } \\
\hline & \multicolumn{2}{|c|}{ Czech Republic } & \multicolumn{2}{|c|}{ Hungary } & \multicolumn{2}{|c|}{ Poland } & \multicolumn{2}{|c|}{ Slovenia } & \multicolumn{2}{|c|}{ Estonia } \\
\hline & 1992 & 1998 & 1992 & 1998 & 1992 & 1998 & 1992 & 1998 & 1992 & 1998 \\
\hline Germany & 582.0 & $3,404.0$ & 878.0 & $3,597.3$ & 300.2 & $4,815.0$ & 126.2 & 384.3 & 16.7 & 44.1 \\
\hline Austria & 76.0 & $1,123.0$ & $1,191.0$ & $1,410.5$ & 77.3 & 693.0 & 296.9 & $1,100.9$ & 0.0 & 16.1 \\
\hline $\begin{array}{l}\text { Belgium- } \\
\text { Luxem- } \\
\text { bourg }\end{array}$ & 118.0 & 184.0 & 144.0 & 707.0 & 16.8 & 592.0 & 5.1 & 15.6 & 0.0 & 6.7 \\
\hline Denmark & 0.0 & 31.0 & 15.0 & 0.0 & 40.7 & 602.0 & 16.5 & 39.4 & 3.3 & 42.2 \\
\hline Spain & 0.0 & 1.0 & 2.0 & 16.3 & 0.0 & 22.0 & 0.0 & 32.6 & 0.0 & 0.0 \\
\hline Finland & 0.0 & 2.0 & 13.0 & 65.3 & 9.6 & 124.0 & 0.0 & 0.0 & 468.5 & 668.0 \\
\hline France & 234.0 & 558.0 & 239.0 & 616.7 & 75.1 & $1,798.0$ & 154.9 & 372.7 & 0.4 & 0.3 \\
\hline $\begin{array}{l}\text { United } \\
\text { Kingdom }\end{array}$ & 0.0 & 799.0 & 230.0 & 717.3 & 54.0 & 811.0 & 5.5 & 130.8 & 0.0 & 33.4 \\
\hline Greece & 0.0 & 0.0 & 4.0 & 9.7 & 14.0 & 5.0 & 0.0 & 0.0 & 5.6 & 5.6 \\
\hline $\begin{array}{l}\text { The Neth- } \\
\text { erlands }\end{array}$ & 51.0 & $3,177.0$ & 421.0 & $2,048.3$ & 239.2 & $6,422.0$ & 11.0 & 111.5 & 19.6 & 49.8 \\
\hline Ireland & 0.0 & 10.0 & 10.0 & 86.8 & 0.0 & 234.0 & 0.0 & 0.3 & 0.0 & 0.5 \\
\hline Italy & 66.0 & 165.0 & 154.0 & 381.0 & 0.0 & 605.0 & 136.3 & 185.9 & 20.9 & 20.7 \\
\hline Portugal & 0.0 & 0.0 & 0.0 & 4.2 & 0.0 & 10.0 & 0.0 & 0.0 & 0.0 & 0.0 \\
\hline Sweden & 0.0 & 271.0 & 51.0 & 93.2 & 63.7 & 542.0 & 0.0 & 7.3 & 333.6 & 515.3 \\
\hline $\begin{array}{l}\text { European } \\
\text { Union (15) }\end{array}$ & $1,127.0$ & $9,725.0$ & $3,352.0$ & $9,753.6$ & 890.6 & $17,275.0$ & 751.7 & $2,381.3$ & 868.5 & $1,402.6$ \\
\hline $\begin{array}{l}\text { United } \\
\text { States }\end{array}$ & 336.0 & 854.0 & 587.0 & $1,925.0$ & 309.0 & $2,867.0$ & 0.0 & 120.7 & 4.1 & 81.2 \\
\hline Japan & 0.0 & 49.0 & 122.0 & 194.7 & 6.0 & 119.0 & 2.8 & 2.7 & 0.4 & 1.5 \\
\hline $\begin{array}{l}\text { Rest of the } \\
\operatorname{OECD}(*)\end{array}$ & 80.0 & 217.0 & 375.0 & 477.4 & 196.0 & $1,690.0$ & 64.0 & 107.6 & 1.5 & 57.2 \\
\hline
\end{tabular}


Examination of the data enables us to observe, amongst other interesting facts, the big presence, as was foreseen, of the EU in the imports of all the candidates and the increasingly significant importance of the CEECs in the market of the Fifteen. In addition, these tables underline the special trade ties that have been established between the candidates and some of the current members, in particular with Germany, Austria, France and Italy. Finally, the more detailed observation of the bilateral data suggests the existence of a certain direct relationship between the geographical proximity of the countries and the intensity of their reciprocal trade.

For their part, the features of the direct investment made by the fifteen Member States of the EU, the U.S.A., Japan and the other members of the OECD in the candidate countries are shown in TABLE 3. Two of these are worth special mention: the exceptional concentration of investments in Hungary, Poland and the Czech Republic and the relative coincidence between the leading OECD investor countries in the CEECs -particularly Germany, Austria and France $^{6}$ - and the ones that play a major part in the supply of their imports. This particular aspect stands out more clearly when we analyse the correlation between both variables for the whole period, as this gives rise to a coefficient of $61 \%$. In addition, there are "case studies" (EBRD, 1999; World Bank, 2000) which further support the idea about the essential influence that is exerted by foreign investment in laying down the trading patterns of the CEECs, not only in the geographical aspect, which is analysed here, but also as regards the sectoral composition of the trade flows.

Moreover, there is evidence that - besides the afore-mentioned association between direct investment and importing- there is a positive relationship between the receipt of foreign capital by the CEECs and their exporting capacity, as an outcome of the strategy apparently being applied by the multinationals of using these countries as production centres and exporting platforms (See Lankes and Venables, 1997).

In short, the features found in the trading patterns of the CEECs with the OECD countries suggest that the attempts that are made to explain them should include amongst the explanatory variables: distance, direct investment and ones that enable us to approach the existence of different trading regimens.

\footnotetext{
${ }^{6}$ It should be pointed out that the favourable tax conditions offered by The Netherlands lead to a distortion in the valuation of the direct investments made by this country. To be specific, these are overvalued through including investments from other countries that use The Netherlands as a platform
} 


\section{Theoretical Framework and Empirical Model}

In accordance with what has just been said, and in order to explain the features observed in the trade adjustment of the former communist countries which are now applying to join the EU, it seems wise to resort to the new trend in the analysis of international trade which has developed from the renewed interest in geography aroused by the appearance of Krugman's book (1991), which is usually identified as "new economic geography" or, more specifically as "geography and trade" models.

Accordingly, although it is by no means our intention to conduct a survey of this literature, because there are already several available, -i.e.: Ottaviano and Puga's (1998) and Schmutzler (1999)-, we will just discuss a few of the ideas put forward by this new trend and which may orientate the empirical analysis proposed in this paper. The first thing that has to be pointed out in this respect is the emphasis that is laid in all these models on location and, therefore, on distance, transport costs and, in general, the spatial dimension of any economic activity. In addition to this, the new geography and trade models underline the existence of growing returns to scale which are at the root of the uneven distribution of economic activity. In fact, the trade-off between growing returns to scale and transport costs is the crucial element that has been stressed since the pioneering models, like that of Krugman and Venables (1990), and which, as is postulated in them, leads companies to be located close to the large markets. In this respect, it is also claimed that there are externalities of a spatial nature -the so-called economies of agglomeration- which may give rise to processes of accumulation of wealth in the places that have benefited initially from the localisation of a significant set of activities.

As regards both the goods and services trade and mobility of factors (capital and labour), Preferential Trade Agreements are naturally another essential piece in models of this type, as it modifies the costs of access to the markets and alters the relative prices of goods and factors ${ }^{7}$.

Finally, this new trend in the analysis of international trade underlines the importance of the decisions made by the multinationals. However, the efforts made to integrate imperfect competition trade models with ones that attempt to explain the behaviour of the multinationals and with location models are still few

\footnotetext{
${ }^{7}$ In this respect, for the context of European integration Smith and Venables (1988) had already maintained that the most important effects of integration stem from the reduction in the degree of segmentation that takes place in the markets.
} 
but necessary (references to them are offered in Markusen, 1998, and Ottaviano and Puga (1998)). It should be said, furthermore, that such modelisations generally go on using the ideas on the causes and effects of the multinational companies that are supported in Hymer's seminal paper (1960) and which by virtue of the accumulation of contributions -qualifying rather than substantive- have given rise to the OLI paradigm ${ }^{8}$ formulated initially in Dunning (1974).

Although recent literature on geography and trade contains other interesting ideas, these refer to more disaggregated contexts, whether in the spatial or in the sectoral aspect, which are not subject to analysis in this paper. It therefore does not seem necessary to go further into them here but rather to proceed with the formulation of the empirical model.

Therefore, taking into consideration the ideas from the geography and trade literature and their apparent compatibility with the stylised facts of CEEC trade patterns with the OECD countries, we now put forward an empirical model that seeks to identify the factors determining the trading patterns observed and, in the last resort, to contribute useful evidence about the possible trade effects of their joining the EU. More specifically, its purpose is explaining the behaviour displayed by the bilateral shares of the developed countries identified as the following three subgroups as a whole: the ones forming the EU, the candidates, and the other member countries of the OECD and, on this basis, confirm whether, as established in the regional integration models, the trade relations with the future partners -which already benefit from an Association Agreement- are stronger and more dynamic than those with third countries.

Specifically, the specification of the model, formulated in panel terms and with the variables expressed in logarithms, is:

$$
\begin{aligned}
& \text { lshare }_{j t}^{i}=\beta_{1} \text { lregdp }_{j t}^{i}+\beta_{2} \text { lfdixm } \text { flt }_{t}^{i}+\beta_{3} \text { fdimx }_{j t}^{i}+\beta_{4} \text { lffdix } j_{j t}^{i}+\beta_{5} \text { lreer }_{j t}^{i}+\beta_{6} \text { ldist }_{j}^{i}+\sum_{k=1}^{9} \delta_{k} D_{k} \\
& +\varepsilon_{i t}
\end{aligned}
$$

where the meaning of each of the variables included in the equation is as follows:

share $_{j t}^{i}=$ share of exports from country $j$ to $i$ in the total imports of $i$. regdp $p_{j t}^{i}=$ Gross Domestic Product of the exporting country $(j)$ vs. the GDP of

\footnotetext{
${ }^{8}$ As known the OLI (Ownership, Location, Internalisation) paradigm postulates that FDI is explained by advantages of owing property, which companies acquire by generating some type of intangible asset vis-a-vis the firms in the host country, along with the exploitation of the advantages of location and the benefits of internalisation.
} 
the set of countries of the sample (OECD, Slovenia and Estonia).

fdixm $_{j t}^{i}=$ Stock of direct investment maintained by the exporting country $(j)$ in the importing country $(i)$.

$\operatorname{fdim}_{j t}^{i}=$ Stock of direct investment maintained by the importing country $(i)$ in the exporting country $(j)$.

$t f d i x_{j t}^{i}=$ Stock of total direct foreign investment in the exporting country $(j)$ in respect of its GDP after deducting the investment maintained by the importing country $(i)$.

$\operatorname{reer}_{j t}^{i}=$ Real effective exchange rate of the exporting country $(j)$ vs. the other competitors in the importing country $(i)$.

$d i s t_{j}^{i}=$ distance between countries $i$ and $j$, unvarying over time.

$D_{k}=$ Set of Dummies representing the different trading areas in accordance with the origin and destination of each of the three defined -EU, candidate countries and third countries-

And where subscript $t$ represents the time period. As mentioned, the set of countries considered is the OECD plus Estonia and Slovenia, which means that the number of bilateral flows amounts to $870(30 \times 30-30)^{9}$, and the time period treated is $1988-1998(\mathrm{t}=11)^{10}$.

The economic justification of each of the variables used in the equation and the sign expected after their estimation are as explained below ${ }^{11}$.

The relative GDP of the exporting country ( $r e g d p$ ) -which is specified as the real GDP of the exporting country vs. the real GDP of the set of countries of the sample- reflects the relative size of the exporting country's market and, therefore, it may be interpreted as a measure of its capacity to exploit economies of scale. In this respect, the starting hypothesis is that the relatively large countries will be better equipped to take advantage of the economies of scale and, therefore, of achieving a bigger market share in the country to which they direct their exports. So the sign of this regressor is expected to be positive.

\footnotetext{
${ }^{9}$ The data for Belgium and Luxembourg are provided together.

${ }^{10}$ Being an incomplete panel, the number of observations finally used is 5664 , as we had to discard the information of 236 individuals and of certain periods of the others due to the existence of zeros in the stocks of direct investment -note that since variables are expressed in logarithms, when the stock is equal to zero, it has to be considered a missing value- and to the fact that Slovenia and Estonia did not exist as countries until 1992.

${ }^{11}$ Appendix I contains an explanation of how the variables were worked out and the sources used in their construction.
} 
The following three explanatory variables attempt to capture the trade strategies that are apparently, according to the evidence available, implemented by the multinational companies (see, for instance, Dunning (1993), Markusen (1995, 1998) and Martin and Velazquez (2002) and the references that are offered there). Basically, the two most frequent ones are considered here: invest in the countries in order to generate distribution channels for their products, or invest so as to take advantage of location offered by the recipient countries with a view to reducing their production costs and from there export to the world, i.e. use the recipient countries as an "exporting platform". Although these strategies may be implemented at the same time, the usual thing is for one of them to prevail. Now, if the first strategy were applied, the result obtained would be that the larger the investment that the exporting company maintains in the importing country (fdixm), the greater the former's share would be in the latter's market. In other words, the estimation would give a significant positive coefficient for this variable.

For its part, the existence of an export-oriented strategy would be to some extent reflected through obtaining significant positive coefficients not only for the variable that measures the importing country's investment stock in the exporting country $(\operatorname{fdim} x)$, but also for the one that measures the rest of the total foreign investment stock (tfdix).

To examine the possible influence of prices on the winning of international markets, we have used the real effective exchange rate of the exporting country vs. the other competitors in the importing country (reer). It has been constructed in this way because, being the dependent variable defined in terms of export shares, it seems that the most adequate is to take into consideration the ratio between the exporter's prices and those of the other trading rivals in that market. Note that, as the calculation of the variable reer, thus defined, is expressed as the competitor's price vs. the exporter's price (see appendix I), the expected sign is positive.

Distance (dist) is used as a proxy for the transport costs and cultural proximity between two countries. In this respect, as is normally assumed in the numerous versions of the gravity models that have been used to try and verify the recent "new economic geography" theories ${ }^{12}$, this variable is expected to maintain an

\footnotetext{
${ }^{12}$ As an illustration, see Frankel et al. (1995), Deardorff (1998) and Rauch (1999). In addition, in Martin (1995) a gravity model is already applied with good results to predict precisely the impact of the Association Agreements that the EU had entered into shortly before with the CEECs.
} 
inverse relationship to trade. Accordingly, it is assumed here also that between countries competing in a market, the ones that are closest to this market, ceteris paribus, will have a higher share. The expected sign of this variable is therefore negative.

Finally, the set of dummies included in the model serve to examine the differences recorded between trading areas ${ }^{13}$ which cannot be explained on the basis of the model regressors and which, therefore, might be attributable, amongst other factors, to the existence of different formal integration bonds. Accordingly, comparison between the dummies reflecting trade between the CEECs and the EU vis-a-vis those referring to trade between the former and third countries will help to check out the impact on trade of the higher degree of formal integration (by way of the Association Agreements) achieved between both areas.

\section{Econometric Estimation and Results}

To estimate the model, we have applied panel methodology for two reasons. The first one is the probable existence of individual country effects not included in the estimation -different legislation, cultural aspects, etc.- which could generate a problem of omitted variables. The second reason is the possibility that such individual effects could cause, as the case may be, a problem of inconsistency if they were correlated with the other explanatory variables. As is known, however, this problem can be detected and addressed through estimating with panel techniques and by using Hausman's test (Hausman and Taylor, 1981). In fact, on estimating the model in this way, we have verified that the value obtained for this test rejects the null hypothesis of absence of correlation between the fixed effects and the explanatory variables. The right procedure, therefore, is to use the WITHIN estimator, the only one that proves consistent in such circumstances.

The drawback of this estimator is, however, the loss of the coefficients of the unvarying time variables. However, if we apply the methodology proposed in

\footnotetext{
${ }^{13}$ To be specific, the dummies estimated are: eueu, euca, eure, caca, caeu, care, reeu, reca and rere. The first two letters refer to the origin of the flows and the second two to the destination. In other words, EU, $\mathrm{CA}$ and RE reflect the European Union, the candidate countries and the rest of countries, respectively. For instance, euca would reflect trade between the European Union and the candidate countries when the source country is the EU.
} 
Table 4. Estimation Results

\begin{tabular}{|c|c|}
\hline \multicolumn{2}{|l|}{ Dependent variable: export share (share) } \\
\hline Method of estimation & WITHIN \\
\hline Relative GDP of exporting country vs. the GDP of the sample (regdp) & $\begin{array}{l}0.345934 \\
(4.59605)\end{array}$ \\
\hline $\begin{array}{l}\text { Stock of direct investment that the exporting country holds in the importer } \\
\text { (fdixm) }\end{array}$ & $\begin{array}{l}0.016258 \\
(2.70623)\end{array}$ \\
\hline $\begin{array}{l}\text { Stock of direct investment that the importing country holds in the exporter } \\
\text { (fdimx) }\end{array}$ & $\begin{array}{r}0.015349 \\
(2.47560)\end{array}$ \\
\hline $\begin{array}{l}\text { Stock of total foreign direct investment in the exporting country compared } \\
\text { with its GDP (after deducting that held by the importer) (tfdix) }\end{array}$ & $\begin{array}{l}0.054050 \\
(4.67570)\end{array}$ \\
\hline $\begin{array}{l}\text { Real effective exchange rate of the exporting country compared with the other } \\
\text { competitors in the importing country (reer) }\end{array}$ & $\begin{array}{l}0.064394 \\
(2.12232)\end{array}$ \\
\hline Distance (dist) & $\begin{array}{l}-0.673738 \\
(-52.5157)\end{array}$ \\
\hline Intracommunity trade (eueu) & $\begin{array}{c}2.25701 \\
(25.0202)\end{array}$ \\
\hline Trade between the EU and the CEECs (euca) & $\begin{array}{c}2.37779 \\
(15.8424)\end{array}$ \\
\hline Trade between the EU and third countries (eure) & $\begin{array}{c}2.44113 \\
(22.6586) \\
\end{array}$ \\
\hline Trade between candidate countries and the EU (caeu) & $\begin{array}{l}0.834760 \\
(8.72210)\end{array}$ \\
\hline Intra-CEEC trade (caca) & $\begin{array}{c}1.88803 \\
(10.6530)\end{array}$ \\
\hline Trade between the CEECs and third countries (care) & $\begin{array}{l}0.197212 \\
(1.53584)\end{array}$ \\
\hline Trade between third countries and the EU (reeu) & $\begin{array}{c}1.99120 \\
(18.1383)\end{array}$ \\
\hline Trade between third countries and the CEECs (reca) & $\begin{array}{c}1.34983 \\
(10.5336)\end{array}$ \\
\hline Trade between third countries (rere) & $\begin{array}{c}3.02986 \\
(24.7634)\end{array}$ \\
\hline Adjusted R2 & 0.66473 \\
\hline Hausman's test (CHIQ(5)) & 36.608 \\
\hline Number of observations & 5664 \\
\hline Number of individuals & 634 \\
\hline Period & $1988-1998$ \\
\hline
\end{tabular}

Arellano and Bover (1990), the coefficients associated with these variables may be obtained. For this purpose, simply: the residuals of the original model are recovered, and then they are regressed versus the unvarying time variables, thus 
obtaining their coefficients ${ }^{14}$.

Now, the results obtained after estimating the model with the procedure that has just been described emphasize -as is shown in TABLE 4- that, in general, the explanatory variables of our model present coefficients compatible with the expected values both in terms of sign and magnitude. Accordingly, we have to stress that the results offer additional evidence as to the influence of direct investment in the trading patterns of the recipient countries. Specifically, on the one hand, it may be observed that foreign investment is used as a channel of supply for the recipient country's market (as is shown in the coefficient of the variable fdixm), and on the other, evidence is also found that the investor implements strategies based on using the recipient country as an "exporting platform" (the coefficients of the variables fdimx and tfdix show significant positive values). This result seems of particular interest with a view to the aim of this paper, insofar as it provides evidence that the exporting capacity (and strategy) of the candidates from the East, which -as Hungary, the Czech Republic or Poland- have a considerable stock of foreign investment, is influenced significantly by the multinationals, which to some extent leads to a more awkward situation for the exports of partners that -as is the case of Spain- have barely invested in them.

This paper also offers evidence in relation to the importance of economies of scale in determining export shares. Thus, when the exporting country raises its relative GDP one percentage point, its export share rises $0.34 \%$ in the other countries. The same thing also happens with the coefficient associated with the real effective exchange rate, with a value of 0.064 .

In addition, it should be pointed out that the coefficients associated with unvarying time variables are the ones anticipated a priori. As for distance, its sign and its magnitude show that it is a factor that has an unfavourable effect on export shares. In this paper, therefore, additional evidence is offered on the influence of distance and, consequently, of transport costs (and cultural differences, which are usually related to distance) in determining foreign trade patterns.

Finally, as regards regional dummies -which are the ones that reflect the effects of the integration of the candidate countries in the EU- we find that the increase in

\footnotetext{
${ }^{14}$ Note that, although in principle the values of the dependent variable -export shares- range between 0 and 1 , since it is being specified in logarithms, it has only an upper limit which is not likely to be exceeded. Hence it does not appear necessary to use a logistical transformation. In any case, we have test that, as could reasonably be expected, none of the predictions made with the estimation method used here exceeds this limit
} 
the export shares of the EU in the CEECs, euca, is sharper than the increase in those of third countries, reca (the coefficients are 2.38 and 1.35, respectively), which suggests that -as was to be expected- the Association Agreements have encouraged the orientation of the trade of the CEECs towards the EU. This fact is further endorsed after applying an $\mathrm{F}$ test and confirming that the coefficients of the dummies referring to the EU and to third countries are statistically different ${ }^{15}$.

As for the coefficients that refer to the importance of the CEECs in the EU and third country area markets, the resultant values -0.83 for the variable caeu and 0.20 for care, although the latter is not significant ${ }^{16}$ - also show that the integration process through which the candidate countries are passing has a positive effect on determining the shares once the other effects already considered in the estimation have been discounted.

Additional information that may be drawn from these coefficients is the impact on the balance of trade of the CEECs with the EU and with third countries. Indeed, if the coefficients of the dummies are compared, it may be found that the ones that refer to the EU are higher than those associated with the third country area.

Since the results that are obtained for the coefficients of the dummies are clearly purged of the influence of the other explanatory variables of the model, all the features that have just been commented on the basis of them, about the differences in the trading record of the CEECs with the EU vis-a-vis with the rest of the OECD, may be attributed to some extent to the trade impact associated with the increased openness of the candidate countries in relation to their future EU partners, as stipulated in the Association Agreements. In this respect, it seems reasonable to think, moreover, that all the features of the trade adjustment detected here will be accentuated within the framework of the full integration of the CEECs scheduled for the near future.

\section{Conclusions}

The results obtained in this study may be interpreted in two ways. Thus, on the one hand, it provides additional evidence that enables us to improve our

\footnotetext{
${ }^{15}$ Specifically, the value obtained after comparing the original model -different dummies- with the restricted one -equal dummies- is 18.76, while the critical value of an $F_{1,5654}$ is 3.84. This therefore enables us to reject equality in the coefficients.

${ }^{16}$ In this case too we did a crosscheck to confirm that the coefficients are statistically different. The result of this test was 27.24 , so the hypothesis of equality in the coefficients is again rejected.
} 
knowledge of the factors that are determining the trading patterns between the member countries of the OECD. In this respect, besides corroborating the importance of distance (transport costs) and of economies of scale, new evidence is supplied on the influence of foreign investment in the importing and exporting activity of the recipient countries. These results suggest, therefore, how advisable it is that not only the efforts that are made in the field of research to understand the nature of international trade, but also those devoted to the design and application of policies in this area, should take trade and the activity of the multinationals into joint consideration.

In addition, the results of this study, however, primarily offer valuable information with a view to predicting the trade impact of enlargement of the EU with the accession of the CEECs. In this respect, there are several lessons that may be drawn from what we have learnt about the trade adjustments that have taken place during these years of validity of Association Agreements, which have meant a substantial elimination of the barriers to trade and of controls on direct investment between the EU and the future members.

First of all -and, on the basis of the values obtained for the dummies that reflect the possible differences between the three reference areas-, we have been able to confirm that the Association Agreements have given rise to a strengthening of the trade relations between the CEECs and the EU, greater than that recorded with the rest of the OECD. One may think, therefore, that this trend is going to keep on after the accesion of the CEECs to the EU. Another important lesson to be drawn when trying to evaluate the subsequent trade adjustments that may take place when the integration of the CEECs is put into effect is that these will largely be determined by the strategies of the multinationals settled in them.

\section{Acknowledgements}

The authors gratefully acknowledge comments received to a previous version of this paper in the 4th International Workshop on European Economy, organised by CEDIN, Lisbon (Portugal), 25-26 May, 2001 and in the VII Jornadas de Economia Internacional, Malaga (Spain), 21-23 June, 2001 organised by the Spanish Chapter of the International Economics and Finance Society, IEFS. We also thank the useful comments received from two anonymous referees. Financial support from Science and Technology Minister of Spain (CICYT Project, SEC 2000-0751-C03-01) is gratefully acknoweldged. 


\section{APPENDIX I: Description of the variables used in the model estimated}

The variables included in the model estimated are taken from the Sectoral Data Base of the European Economy Group (SDB-EEG) of the Universidad Complutense de Madrid. Its preparation and the sources used for this are explained below:

Export shares $\left(\operatorname{share}_{j t}^{i}\right)$ : The definition of this variable is the share that the exports which country j makes to country $i$ represents of the total imports of $\mathrm{i}$. It is constructed from the standpoint of the importing country given the greater reliability of flows recorded in this way. Import figures are expressed in US dollars. For the countries of the OECD the source used is ITCS - International Trade by Commodity Statistics of the OECD. To complete the trading flows of Slovenia and Estonia we have used the International Monetary Fund (IMF) publication Direction of Trade Statistics Yearbook.

Real Gross Domestic Product at market prices $\left(r e g d p_{j t}^{i}\right)$ : For the countries belonging to the OECD -including the three recently incorporated CEECs-, it is calculated from OECD data: National Accounts, Volume I: Main Aggregates. For the other two Eastern countries the sources used are: Statistical yearbook on candidate and South-East European countries, of the European Commission, and the publication issued by the United Nations (UN) Economic Survey of Europe. The GDP deflators are obtained from the same publications and the base year chosen is 1993. As regards the exchange rates used to express all the variables in US dollars, we have used those given in the International Monetary Fund (IMF) publication International Financial Statistics.

Stocks of bilateral foreign direct investment $\left(f d i_{i j t}\right)$ : For the OECD countries the data for the construction of fdixm and fdimx are taken from the International Direct Investment Statistics Yearbook, whereas for Estonia and Slovenia we had to resort to the data published by the National Banks of both countries. As for the variable tfdix -being the total stock of foreign direct investment that a country receives-, it is estimated from the receiving country's data, which is the only one that seems feasible, because otherwise it would be necessary to know the statistics of all the countries in the world. The stock of total foreign direct investment is divided by the GDP of the country receiving the investment so as to rule out the size effect. The last 
of the variables, sidext, being the total stock of foreign investment that a country receives, is estimated from the receiving country's data, which is the only one that seems feasible. The latter is divided by the GDP of the country receiving the investment so as to rule out the size effect.

Real effective exchange rate $\left(\right.$ reer $\left._{j k}\right)$ : It is defined as the real exchange rate of the exporting country (j) vs. the other competitors $(k)$ in the importing country, i.e.

$$
\text { reer }_{j k}=\prod_{j \neq k} e r_{j}^{S j} \cdot \frac{\prod_{j \neq k} P_{j}^{S j}}{P_{j}}
$$

where $e r$ is the nominal exchange rate defined as national currency -foreign currency, $P$ is the consumer price index, $S$ is the weight used, defined as the volume of trade of the exporting country over the total volume of trade of the countries of the sample and the subscripts $j$ and $k$ refer to the exporting country and the other competitors, respectively.

The consumer price indexes used for the construction of this variable are obtained from the OECD publication National Accounts, Volume I: Main Aggregates. In the case of Estonia and Slovenia there were two prime sources: the European Commission Statistical yearbook on candidate and South-East European countries and the UN Economic Survey of Europe.

Distance $\left(\right.$ dist $\left._{i j}\right)$ : It is the distance between the capitals of the trading countries. It is taken from the Program PC Globe.

\section{References}

Arellano, M. and Bover, O. (1990), La econometria de los datos de panel, Investigaciones Economicas, Segunda Epoca, XIV(1), 3-45.

Buch, C.M. and Piazolo, D. (2000), Capital and Trade in Europe and the Impact of Enlargement, Kiel Working Paper, 1001, Kiel Institute of World Economics, Germany.

Deardorff, A. V. (1998), Determinants of Bilateral Trade: Does Gravity Work in a Neoclassical World?', in The Regionalization of the World Economy (Ed.) Frankel, J. A., NBER, The University Chicago Press, Chicago and London, pp. 7-32.

Dunning, J.H. (1974), Economic Analysis and the Multinational Enterprise, Allen \& Unwin.

Dunning, J.H. (1993), Multinational Enterprises and the Global Economy, Addison

Wesley, Reading, Massachusetts.

EBRD (1999), Transition Report, London. 
Frankel, J., Stein, E. and Wei, S. (1995), Trading blocs and the Americas: The natural, the unnatural, and the super-natural, Journal of Development Economics, 47, 61-95.

Hausman, J.A. and Taylor, W.E. (1981), Panel Data and Unobservable Individual Effects, Econometrica, 49, 1377-1398.

Hymer, S.H. (1960), The International Operations of National Firms: A Study of Direct Investment, Ph.D. Thesis, MIT (Published by MIT Press in 1976).

Krugman, P.R. (1991), Geography and Trade, MIT Press, Cambridge, Massachusetts.

Krugman, P.R. and Venables, A.J. (1990), Integration and the Competitiveness of Peripheral Industry, in Unity with Diversity in the European Community (Eds.) Bliss, C. and Braga de Macedo, J. Cambridge University Press, Cambridge.

Lankes, H.P and Venables, A.J. (1997), Foreign direct investment in Eastern Europe and the former Soviet Union: Results from a survey of investors, in Lessons from the Economic Transition. Central and Eastern Europe in the 1990s (Ed.) Zecchini, S., Kluwer Academic Publishers and OECD, Norwell, Massachusetts.

Markusen, J.R. (1995), The Boundaries of Multinational Enterprises and the Theory of International Trade, Journal of Economic Perspectives, 9(2), 169-189.

Markusen, J.R. (1998), Multinational Firms, Location and Trade, World Economy, 21(6), 733-756.

Martin, C. (1995), El impacto comercial de los Acuerdos de la UE con los paises del Este, Papeles de Economia Espanola, 63, 269-284.

Martin, C. and Velazquez, F.J. (2002), Determinants of Net Trade Flows in the OECD: New Evidence with Special Emphasis on the Former Communist Members' Review of International Economics 10(1), 129-139 (forthcoming).

Ottaviano, G. and Puga, D. (1998), Agglomeration in the Global Economy: A Survey of the 'New Economic Geography, World Economy, 21(6), 707-731.

Rauch, J. (1999), Networks versus markets in international trade, Journal of International Economics, 48(1), 7-35.

Schmutzler, A. (1999), The New Economic Geography' Journal of Economic Surveys, vol. 13(4): 355-379.

Smith, A. and Venables, A.J. (1988), Completing the Internal Market in the European Community: Some Industry Simulations, European Economic Review, 32, 1501-25. World Bank (2000), Progress Toward the Unification of Europe, Washington, D.C. 